\title{
H1-8 wt Allele
}

National Cancer Institute

\section{Source}

National Cancer Institute. H1-8 wt Allele. NCI Thesaurus. Code C162810.

Human $\mathrm{H} 1-8$ wild-type allele is located in the vicinity of $3 q 22.1$ and is approximately $8 \mathrm{~kb}$ in length. This allele, which encodes histone $\mathrm{H} 100$ protein, is involved in chromatin structural regulation during oogenesis and embryogenesis. 